\title{
UNILATERAL USE OF ARMED FORCE AND THE CHALLENGE OF HUMANITARIAN INTERVENTION IN INTERNATIONAL LAW
}

\author{
Mohammad Taghi Karoubi ${ }^{*}$
}

\section{INTRODUCTION}

Apart from the important provision of Article 51 which admits unilateral forcible action in the exercise of the right of individual and collective self-defence against an armed attack, the use of force under the United Nations Charter is intended to be monopolized by the Organization. ${ }^{1}$ This monopoly finds its expression in the provision concerning the prohibition of the unilateral resort to force by states in Article 2(4) of the UN Charter where, for the first time, direct reference was made to not resorting to force, which has a broader meaning than not resorting to war, the formula used in the Pact of Paris. ${ }^{2}$ The principle of the prohibition on the use of force or threat of force has been repeatedly stressed in United Nations General Assembly (UNGA) resolutions. ${ }^{3}$ The principle, today, is not only a conventional general principle, but it has also become a principle of customary international law as indicated by the International Court of Justice (ICJ) in its decision in the Nicaragua

\footnotetext{
* Lecturer in Law, Tehran, Iran. LLB, Tehran University, LLM. and Ph.D., Hull University (UK).

1 See H. Waldock, "The regulation of the use of force by individual states in international law", 81 RCADI, 1952, 455. See also H. McCoubrey and N.D. White, International Law and Armed Conflict, Aldershot: Dartmouth Press, 1992; I. Claude, "The Blueprint", International Conciliation, No. 532, March 1961; Id., "United Nations Use of Military Force", 7-2 JAC, June 1963; R. Hoggins, United Nations Peacekeeping 1946-1967: Documents and Commentary, Vol. 1, London: Oxford University Press, 1969; A. James, The Role of Force in International Order and United Nations Peace-keeping, The Ditchley Foundation, May 1969; W.J. Durch, (ed.), The Evaluation of UN Peacekeeping, New York: St Martin's, 1993; D.W. Bowett, United Nations Force, London: Stevens and Sons, 1964; F. Seyersted, United Nations Forces in the Law of Peace and War, Leiden, London: A.W. Sijthoff, 1966; D.J. Scheffer, Law and Force in New International Order, Boulder: Westview Press, 1991.

${ }^{2}$ For more details about the Pact of Paris, see J.L. Brierly, "Some implications of the Pact of Paris", 10 BYIL (1929) 208. See also Q. Wright, "The meaning of the Pact of Paris", 27 AJIL (1933); F. Kellogg, "The war prevention policy of the U.S.A.", 22 AJIL (1928).

3 See Declaration on Friendly Relations (1970), GA Res. 2625; Definition of Aggression (1975), GA Res. 3314; Declaration on the Non-Use of Force (1988), GA Res. 42/22.
}

Asian Yearbook of International Law, Volume 10 (B.S. Chimni et al., eds.)

(C) 2005 Koninklijke Brill NV. Printed in The Netherlands, pp. 95-124. 
Case $^{4}$ and the Legality of the Threat or Use of Nuclear Weapons. ${ }^{5}$ It is also included by many writers in the commanding principles of international law (jus cogens). ${ }^{6}$

In spite of this restriction and deep transformation in the legal system, ${ }^{7}$ however, some unilateral military actions in the final decade of the twentieth century took place under claims of protecting innocent people from mass human rights violation by oppressive Governments. This kind of justification can be seen in the US statement regarding the US's military action in Iraq in 1996, as well as in the rationale given by NATO leaders during the Kosovo crisis in $1999 .{ }^{8}$ For example, US President Clinton and UK Prime Minister Blair, during NATO's action in March 1999, emphasized that the humanitarian catastrophe led the allies to act, and the choice

4 The International Court of Justice upheld the authority of the Charter prohibition contained in Article 2(4). The Court in its decision in the Nicaragua Case held that the principles of Article 2(4) were not only treaty law but the substance of customary international law as well. Military and Paramilitary Activities in and Against Nicaragua (Nicar. v. US) (Merits), ICJ Rep. 1986 at 14, paras 187-192. States have on many occasions expressed their individual support for the Article, and such expressions of support have come from many different sectors of the community of states. See R. Higgins, "The attitude of western states towards legal aspect of the use of force", in A. Cassese (ed.), The Current Legal Regulation of the Use of Force (1986), at 435; B. Szego, "The attitude of socialist states towards the international regulation of use of force", ibid.

5 See the Legality of the Threat or Use of Nuclear Weapons case, ICJ Rep. 1996, at 226, para 70.

6 See B. Simma, "NATO, the UN and the use of force: legal aspects", 10 EJIL (1999), at 1-4. See also A.C. Arend and R.J. Beck, International Law \& the Use of Force, London, New York: Routledge Press, 1993, at 31-6; G. Christenson, "The World Court and jus cogens", 81 AJIL (1987); N. Ronzitti, "Use of force, jus cogens and state consent", in Cassese, n. 4.

7 In the period between the League of Nations and the United Nations a profound change occurred in international law in regard to the use of armed force in international relations among states. For more information about the issue, see F. Northedge, The League of Nations: Its Life and Times 1920-46, Leicester: Leicester University Press, 1986. See also H. Miller, The Drafting of the Covenant, Vol. I; A.E. Hindmarsh, Force in Peace, Force Short of War in International Relations, Cambridge, Mass.: Harvard University Press, 1933; G. Scott, The Rise and Fall of the League of Nations, London: Hutchinson, 1973; E.H. Carr, International Relations between the Two World Wars 1919-1933, New York: St Martin Press. 1967; S. Mark, The Illusion of Peace, International Relations in Europe 1918-1933, London: Macmillan Press, 1976.

8 The US President, Clinton, tried to justify the US's action for the protection of innocent Kurdish people and stated that, "Saddam's ... methods are always the same - violence and aggression, against the Kurds ...". See Clinton speech at http://www.the-times.co.uk/cgi-bin/BackIssue? Available in September 2000. See also The Times, "US threatens to attack again", September 3, 1996, at http:// www.the-times.co.uk/cgi-bin/BackIssue? Available in September 2000. See the Prime Minster of Great Britain, John Major, when he said, "we are concerned about any external threats he produces and repression of his own people and it is against that the United States acted". See N.D. White, "Commentary on the protection of the Kurdish safe-haven: Operation Desert strike", 2 Nottingham JACL (December 1996), at 201. See also C. Antonopoulos, "The unilateral use of force by states after the end of the cold war", 4 Nottingham JACL (June 1999), at 152; S.P. Subedi, "The doctrine of objective regimes in international law and the competence of the United Nations to impose territorial or peace settlements on states", 36 GYIL (1994); D.P. O'Connell, "Continuing limits on United Nations intervention in civil war", 67 Ind.LJ (1992). 
was to do something or do nothing. ${ }^{9}$ President Clinton stated that the action was designed to avert a humanitarian catastrophe, to preserve stability in a key part of Europe, and to maintain the credibility of NATO. ${ }^{10}$ The US emphasized the goals of the NATO action, rather than a basis in international law, for authorization of the use of force. ${ }^{11}$ The permanent representative of the UK in the United Nations Security Council, Jeremy Greenstock, also stated:

We have taken this action with regret, in order to save lives. It will be directed towards disrupting the violent attacks being committed by the Serb security forces and weakening their ability to create a humanitarian catastrophe. ${ }^{12}$

Solana, the NATO Secretary General, in a press statement emphasized, rather than legality, the moral duty of NATO to "stop the violence and bring an end to the humanitarian catastrophe", and concluded that, "we have a moral duty to do so." 13

The place of the doctrine of humanitarian intervention in international law in the light of the views of adherents of the doctrine, namely, Wolff, ${ }^{14}$ Kant, ${ }^{15}$ Vattel, ${ }^{16}$ Woolsey, ${ }^{17}$ and Arntz, ${ }^{18}$ and of those who opposed the doctrine, such as Hobbes, ${ }^{19}$ Wildman $^{20}$ and Reddie, ${ }^{21}$ will be examined briefly in this article. In doing so, the paper will analyze the tension between sovereignty and human rights in the established international legal order which manifest in the opening words of the United Nations Charter, as well as the attempts of recent scholars such as Cassese

9 See Clinton's Address on Air-strikes against Yugoslavia in the New York Times on 24 March 1999. NYT also cited the full text of Tony Blair's statement on the Kosovo bombing. See also R. Sylvester, "The Blair doctrine: This is an ethical fight ", The Independent, 28 March 1999.

10 See Statement by President Clinton confirming NATO air strikes against the Serbs on 24 March 1999 in the New York Times at www.nytimes.com NYT.

11 Ibid.

12 See Statement in the United Nations Security Council by Jeremy Greenstock, KCMG, Permanent Representative of the UK on 24 March 1999, at http://www.fco.gov.uk/news/newstext.asp?2157, Available in October 2000.

13 See J. Solana, NATO Secretary-General, Press Statement on 24 March 1999 at http://www.nato.int/ docu/pr/1999/p99-041e.htm, Available in October 2000.

14 See C. Wolff, Jus Gentium Methodo Scientifica Peractatuma (tr. J.B. Scott), Washington: Carnegie Endowment for International Peace, Vol. II, 1934.

15 See F.X. De Lima, Intervention in International Law, Uitgeverij Pax Nederland, 1971, at 14-15.

16 See E. Vattel, The Law of Nations: Principles of the Law of Nature, Applied to the Conduct and Affairs of Nations and Sovereigns (tr. Fenwick), Washington: Carnegie Endowment for International Peace, 1916.

17 See T.S. Woolsey, Introduction to the Study of International Law, (4 ${ }^{\text {th }}$ ed.), London: Sampson, Low, Marston, Low and Searle, 1875.

18 See Arntz's view in S. Chesterman, Just War or Just Peace, Oxford: Oxford University Press, 2001.

19 See T. Hobbes, Leviathan, London: Den, 1914.

20 See R. Wildman, Institutes of International Law, London: William Benning, 1849.

21 See J. Reddie, Inquiries in International Law: Public and Private, Edinburgh: William Blackwood and Sons, 1851. 
who tried to justify the doctrine in some circumstances, based on legal or moral grounds.

\section{THE QUESTION OF HUMANITARIAN INTERVENTION BEFORE WORLD WAR II}

Intervention by states for the protection of the lives of their nationals in another state has been a controversial issue among writers from the past until now. Wolff (1679-1754), for example, in his remarkable work, Jus Gentium Methodo Scientifica Peractatuma, rejected the interference of a state in the sovereignty and government of another state based on the equality of states in natural law. ${ }^{22} \mathrm{He}$ argued that by nature all nations are equal to one another, for nations are considered as individuals, free persons living in a state of nature. ${ }^{23}$ Therefore, since by nature all men are equal, all nations are equal to one another. ${ }^{24}$ Wolff further concluded that equality of nations bestows on them equal rights and duties, for the same reason that men's equality gives them the same rights and obligations. ${ }^{25}$ In his view: "Since by nature the rights and the obligations of all nations are the same, and since that is lawful which we have the right to do and lawful which we are alleged not to do or to omit; what is lawful by nature for one nation, that likewise is also lawful for another, and what is not lawful for one is also not lawful for another." ${ }^{26}$ Wolff, in his belief that states have equal rights and duties, went a step further than his predecessors by deliberating upon "interference" by a state with the exercise of sovereignty of another, which he conceded is a delicate issue in international law, as international law bestows equal rights and duties on all states. ${ }^{27}$ For the same reason he maintained that interference in the government of one state by the government of another state is not permissible. ${ }^{28}$ The principle of non-intervention in the sovereignty of a state by another state was strongly supported by Wolff.

In the eighteenth century, Kant, who was largely influenced by the French Revolution in 1789 and by the writings of Rousseau, supported the principle of nonintervention of a state in another state where the state has a republican government. ${ }^{29}$ He stated that, "No state should interfere in the constitution or the government of another state. ${ }^{30}$ It is significant to note that Kant, however, qualified his idea by holding that intervention is illegal only in the case of republican governments;

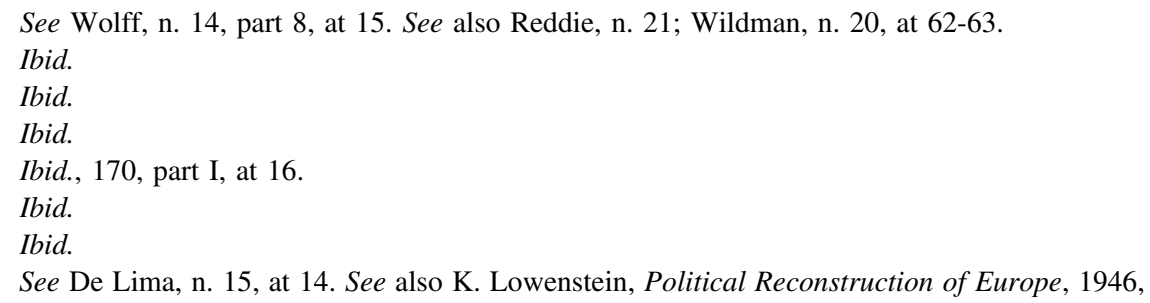


therefore, in other cases, intervention is permissible. ${ }^{31}$ In other words, in his view, the principle of non-intervention was applicable only in relations between republican governments and not in relations between republican governments on the one hand and monarchical governments on the other. For Kant, the intervention of republican governments in the affairs of monarchical governments was justified to bring republican rule in such states. ${ }^{32}$ Two centuries later, in 1990, Weigel and Reisman in some aspects approached the Kant doctrine.

Weigel, in his work, "From Last Resort to End Game", approaches the criterion of right authority from a more secular standpoint, and defines this authority according to the secular political processes that validate it. ${ }^{33}$ Weigel argues that only democratically oriented states or transnational organizations qualify as authorities competent to declare a just war. ${ }^{34}$ To him, in modern times, "democratic election" is a criterion of competent authority. According to this approach, the competent authority requirement was met in all recent wars because the United States authority was "democratically elected" and supported by "open and vigorous debate that directly engaged the moral issues." 35 It is submitted that the authority required for a state to resort to and wage a just war is often so loosely defined in traditional theory that it may be tempting to discount this requirement. Undoubtedly, this is a specification more tightly construed than in traditional just war criteria. The fact that the requirement does not, in practice, discriminate very specifically among possible configurations of authority should not obscure the very important fact that it has the capability to discriminate per se. Here the question is: Does justification of the war directly correspond to the rank order of legitimacy, if the war-making authority of some states is more strongly legitimized than the authority of other states? According to Weigel's terminology, the more democratic state possesses greater legitimacy and therefore, in the case of armed conflict between the US - as the most democratic state in the world - and the rest of the world, while both parties admit the possibility of both sides having a just cause and all other conditions appear to be equal, the US side is more legitimate because it is more democratic! He, indeed, argues in favour of democracy, but we know that the question of what constitutes democracy is subjective rather than objective. The unilateral use of force which recently took place by the US and the UK against Iraq renders the attack to be held to be not only less legitimate, but actually illegitimate. Indeed, military action cannot be justified on the basis that the states concerned are more democratic than the Iraqi regime, itself based on

\footnotetext{
31 Ibid.

32 Kant used the concept of republicanism; today, the concept of democracy is used by some writers in order to justify some interventions. Weigel, in regard to right authority, argues that a more democratic authority possesses greater legitimacy yet he ignored the fact that the question of democracy is subjective rather than objective. Weigel, "From last resort to end game", in E. Decosse (ed.), But Was It Just?, New York, 1992.

33 Ibid., 23.

34 Ibid.

35 Ibid.
} 
military power, but an important point is that the mere existence of a democracy cannot justify war.

Reisman also argued that the term 'sovereignty' constituted an anachronism when applied to undemocratic governments or leaders. ${ }^{36} \mathrm{He}$ argued that unilateral intervention to support or restore democracy did not violate sovereignty. ${ }^{37}$ Reisman then concluded that it was "anachronistic" to say that the US violated Panama's sovereignty in 1989 by launching an invasion to capture its illegitimate head of state. ${ }^{38}$ It is submitted that this is an extreme conclusion presented by Reisman. How is it possible to violate sovereignty of states while the sovereignty still has important roles and a place in contemporary international law? His view is not acceptable and it is illegitimate for one state to interfere in the affairs of another state by the use of force to install a new and more legitimate state; such action is not condoned by jurists.

The exercise of intervention, however, has been recognized and considered in the nature of self-defence or self-preservation, ${ }^{39}$ in the past, by some writers such as Vattel and Wheaton. Vattel, for example, in this regard said, "Whoever wrongs the state, violates its rights, disturbs its peace, ignores it in any manner whatever, becomes its enemy and is in a position to be justly punished. Whoever ill-treats a citizen indirectly injures the state, which must protect that citizen. The sovereign of the injured citizen must avenge the deed and if possible, force the aggressor to give full satisfaction or punish him, since otherwise the citizen will not obtain the chief end of a civil society, which is protection." 40 Accordingly, the state extends itself through its nationals who are a vital part of the concept of statehood and, consequently, the state has a right to protect its nationals. At that time, states exercising this right were free to use whatever means they considered just. Hence, a state could utilize armed force against another state that had violated the rights of its nationals residing in the territory of the latter.

In the nineteenth century, three important interventions took place that merit attention. The earliest example of humanitarian intervention occurred in 1827 by the joint intervention of Great Britain, France and Russia to the aid of Greek insurgence against the Turks. ${ }^{41}$ Stowell argues that it has usually been classed as an instance of humanitarian intervention motivated by the "uncivilized methods" by which that war was being conducted. ${ }^{42}$ The Treaty between Great Britain, France and Russia for the Pacification of Greece, signed at London on 6 July 1827, set forth in the

${ }^{36}$ See M. Reisman, "Sovereignty and human rights in contemporary international law", 84 AJIL (1990), at 866.

37 Ibid.

38 Ibid.

39 See De Lima, n. 15, at 115.

40 See Vattel, n. 16, sects. 18-21.

${ }^{41}$ See C. Fenwick, "Intervention: individual and collective", 39 AJIL (1945), at 650. See also J.P. Fonteyne, "The customary international law doctrine of humanitarian intervention: its current validity under the UN Charter", 4 CWILJ (1974).

${ }^{42}$ See E.C. Stowell, Intervention in International Law, Washington, DC.: John Byrne and Co, 1921, at $126-127$. 
preamble the specific ground on which they justified their intervention. ${ }^{43}$ The second intervention took place following a meeting in Paris on 31 July 1860, of the ambassadors of Austria, Great Britain, France, Prussia and Russia, with a representative of Turkey, when a protocol was adopted and incorporated into a convention signed on 5 December 1860 in order to support Christian minorities in Lebanon and Damascus who were attacked by Druzes and Muslims. ${ }^{44}$ French-occupied parts of Great Syria ${ }^{45}$ and its warships policed the coast from August 1860 to June $1861 .{ }^{46}$

The last intervention was carried out by the US in Cuba at the end of the nineteenth century, in response to reports of atrocities committed by Spanish Military authorities attempting to suppress the insurrection that took place in $1895 .^{47}$ This was the closest example of unilateral humanitarian intervention in the pre-charter state practice. According to Ferrel, approximately 200,000 Cubans died in the camps when the Spanish authorities forced the disaffected population into concentration camps in order to identify revolutionaries, an action which caused genuine outrage in the US. ${ }^{48}$ President Mckinley, in his message to Congress on 11 April 1898, justified the intervention for "the cause of humanity" 49 and then outlined the following justifications for US intervention in the conflict: the protection of US citizens and their property in Cuba, the protection of US commercial interests, and selfdefence.$^{50}$ However, the character of the action has been questioned by writers. ${ }^{51}$ Bowett, ${ }^{52}$ Moore ${ }^{53}$ and Buergenthal, ${ }^{54}$ on the one hand, argued that the US intervention took place for the protection of nationals, property, and as abatement of a nuisance. Fonteyne ${ }^{55}$ and Woolsey, ${ }^{56}$ on the other hand, thought it lacked a clearly humanitarian motive. ${ }^{57}$ They noted that the US acted not on the score of humanity alone, but that American interests were deeply involved and the action might be properly regarded as self-defence. ${ }^{58}$

${ }^{43}$ See E. Hertslet, The Map of Europe by Treaty, Vol. 1, London: Butterworths, 1875, at 769-770.

${ }^{44}$ See id., The Map of Europe by Treaty, Vol. 2, 1875, at 1451-1455.

45 Ibid.

46 Ibid.

47 See R. Ferrell, American Diplomacy: A History, ( ${ }^{\text {rd }}$ edn.), New York: Norton Press, 1975, at 350 .

48 Ibid.

49 Cited in J.B. Moore, The Principles of American Diplomacy, New York: Harper and Brothers, 1918 , at $219-220$.

50 Ibid.

${ }^{51}$ For more discussion see I. Brownlie, International Law and the Use of Force by States, Oxford: Clarendon Press, 1963, at 46.

${ }_{52}$ See D.W. Bowett, Self-Defence in International Law, Manchester: Manchester University Press, 1958 , at 97.

53 See Moore, n. 49, at 208.

${ }^{54}$ See T. Buergenthal, "The Copenhagen CSCE meeting: a new public order for Europe", 11 HRLJ (1990).

55 See Fonteyne, n. 41, at 206

56 See Woolsey, n. 17, at 76.

57 See Fonteyne, n. 41, at 206.

${ }^{58}$ See Woolsey, n. 17, at 76. 
The status of humanitarian intervention in the first half of the twentieth century becomes more problematic. Collective action on the part of the international community being politically difficult, the notion of unilateral intervention by a state or group of states sat uncomfortably with the increasing emphasis on the inviolability of the domestic jurisdiction. The League of Nations neither prohibited nor explicitly supported humanitarian intervention. By acceptance of obligations not to resort to war and "the maintenance of justice and a scrupulous response for all treaty obligations in the declaring of organized reports with one another", the Covenant aimed at peace. The use of force was not outlawed as such, but war was made a matter of concern to the entire League; members were required in the first instance to submit any dispute to arbitration, judicial settlement, or to enquiry by the Council. It is at least arguable that internal human rights violations could have constituted such a dispute, though the Council explicitly disclaimed any capacity to make recommendations on a matter that "by international law is solely within the domestic jurisdiction of [a] party". The Pact of Paris also said nothing of humanitarian intervention, though its tenor is clearly inconsistent with any such right. State parties stated their conviction that "all changes in their relations" should be sought only by pacific means, condemned recourse to war for the "solution of international controversies", and renounced it as an instrument of national policy. There was considerable diplomatic activity concerning reservations to this prohibition, but the reservations were limited to the right of legitimate defence or self-defence.

A group of jurists at the time argue that humanitarian intervention existed as a legal right. They tried to define the theory as the attempt to give a juridical basis to the right of one state to exercise control over the internal acts of another state. ${ }^{59}$ Woolsey ${ }^{60}$ and Arntz ${ }^{61}$ approached Grotius' conception of punitive war and adopted the view that it was representative of civilized government intervening in the affairs of other states. Bluntschli, ${ }^{62}$ and Creasy ${ }^{63}$ recognized the legality of humanitarian intervention based on a state entitled to assert the rights of subjects vis-à-vis their sovereign in certain circumstances. This was the modern equivalent of Grotius' right to wage war on behalf of the oppressed. However, some writers, such as Hobbes, ${ }^{64}$ Wildman, ${ }^{65}$ Reddie, ${ }^{66}$ and Bernard, ${ }^{67}$ were opposed to a right of humanitarian intervention. They rejected all intervention in the sovereignty of another state because

\footnotetext{
59 Chesterman in his work, Just War or Just Peace, cited Antoine Rougier's description of the theory as an attempt to give a juridical basis to the right of one state to exercise control over the affairs of another state. See n. 18, at 36.

60 See Woolsey, n. 17, at 32.

${ }^{61}$ Cited in Chesterman, n. 18, at 36.

62 Ibid.

63 See E.S. Creasy, First Platform of International Law, London: John Van Voorst, 1876.

64 See Hobbes, n. 19.

65 See Wildman, n. 20, at 62-63.

66 See Reddie, n. 21.

${ }^{67}$ See M. Bernard, On the Principle on Non-Intervention, Oxford: J.H. and J. Parker, 1860. See also T.E. Holland, Lectures on International Law, London: Sweet and Maxwell, 1933.
} 
any intervention on their behalf, no matter how great the moral claim, is incompatible with sovereignty. ${ }^{68}$

\section{HUMANITARIAN INTERVENTION AFTER WORLD WAR II}

A strong tendency to the principle of non-intervention was seen at the end of World War II, with its even more terrible results than the First World War. At that time, people once again thought more seriously about confronting the use of force issue at the international level, to prevent war. In this way the international community in general and the major Allied Powers in particular became convinced that yet another effort should be made to establish a universal international organization charged with the management of international conflict. The League had failed in this task, but the new organization, it was believed, would be different. The conduct of Japan in China (1931), Italy in Ethiopia (1935), Germany in both Austria (1938) and Czechoslovakia (1938-9), and of the USSR in Finland (1939-40) and the invasion of Poland by Germany (1939), ${ }^{69}$ repudiated everything for which the League stood. The joint Declaration of Roosevelt, the President of the USA, and Churchill, the Prime Minster of Great Britain, on 14 August 1941, ${ }^{70}$ proclaimed the abandonment of unilateral resort to force and the "... establishment of a wider and permanent system of general security". ${ }^{71}$ They also declared their hope that after the final destruction of the Nazis, a system would be established which would afford to all nations the means of dwelling in safety within their own boundaries and would "bring about the fullest collaboration between all nations in the economies field with the object of securing, for all, improved labour standards, economic advancement and social security." 72 In the Declaration of the United Nations of 1 January 1942, the USA, the UK, the USSR, China and other states in a state of war with the Axis Powers subscribed to the Atlantic Charter of 14 August 1941, stating that they were engaged in a "common struggle" against the Axis. ${ }^{73}$ They also declared that they would pursue the war in co-operation with each other. ${ }^{74}$ This declaration had the effect of attributing to the armed struggle of the anti-Axis coalition the character of a collective war of sanction.

\footnotetext{
68 Ibid.

69 The invasion of Poland by Germany in September, 1939, and the subsequent state of war between Germany, on the one hand, and the UK and France, on the other, is widely accepted as the starting point of the Second World War.

70 Text is available in 35 AJIL, Suppl. 191 (1941).

71 Ibid.

72 Ibid.

73 Text is available in 36 AJIL, Suppl. 191 (1942).

74 Ibid.
} 
The United Nations ${ }^{75}$ Charter in its preamble declares that the new organization was established "to save succeeding generations from the scourge of war, which twice in our lifetime has brought untold sorrow to mankind". It emphasized that the means to end such catastrophe was "... by acceptance of principles and institution of methods, that armed force shall not be used, save in the common interest." The principle of non-intervention generally recognized in the provisions of Article 2(1) on sovereign equality, Article 2(4) on the non-use of force, and Article 2(7) on domestic jurisdiction. According to the San Francisco Conference the principle of sovereign equality contains some elements including a) that states are juridically equal; b) that each state enjoys the rights inherent in full sovereignty; c) that the personality of the state is respected, as well as its territorial integrity and political independence; and d) that the state should, under international order, comply faithfully with its international duties and obligations. ${ }^{76}$

The UNGA through its 1970 Friendly Relations Declaration proclaimed sovereign equality, non-use of force and non-intervention, along with four other principles of the UN Charter, to constitute basic principles of international law. ${ }^{77}$ The Declaration also declares that each state enjoys the rights inherent in full sovereignty, has the duty to respect the personality of other states, and has the right freely to choose and develop its political, social, economic and cultural systems. ${ }^{78}$ According to the Declaration, the territorial integrity and political independence of the state are inviolable. $^{79}$

No state or group of states has the right to intervene, directly or indirectly, for any reason whatever, in the internal or external affairs of any other state. Consequently, armed intervention and all other forms of interference or attempted threats against the personality of the state or against its political, economic and cultural elements are in violation of international law. ... no state shall organize, assist, foment, finance, invite or tolerate subversive, terrorist or armed activities directed towards the violent overthrow of the regime of another state or interfere in civil strife in another state. ${ }^{80}$

The principles of non-use of force and non-intervention have received international judicial recognition in the ICJ twice: in the Corfu Channel case, and in the Case

\footnotetext{
${ }^{75}$ The victorious countries established a new international organization called the United Nations Organization. The UN Charter, sponsored by the United States, Britain, the Soviet Union and China, and originally signed by fifty-one states, was designed to introduce law and order and an effective collective security system into international relations. The charter was approved in 1945 at the San Francisco Conference and entered into force on 24 October 1945.

76 See UNCIO, Doc. Vol. VI, at 457.

${ }^{77}$ See the principle of non-use of force in the Declaration on Friendly Relations in GA. Res. 2625 (XXV), GAOR $25^{\text {th }}$ session, Suppl. No 28 (1970), at 121. See also the Definition of Aggression in GA. Res.3314 (XXIX), GAOR 29 $9^{\text {th }}$ session, Suppl. No 31 (1974), at 142.

78 Ibid.

79 Ibid.

${ }^{80}$ Ibid., $3^{\text {rd }}$ principle.
} 
Concerning Military and Paramilitary Activities in and against Nicaragua. In the former case the Court stated that:

The Court can only regard the alleged right of intervention as the manifestation of a policy of force, such as has, in the past, given rise to most serious abuses and such as cannot, whatever be the present defects in international organization, find a place in International Law. Intervention is perhaps less admissible in the particular form it would take here; for from the nature of things, it would be reserved for the most powerful States and might easily lead to preventing the administration of international justice. ${ }^{81}$

In the latter case, the ICJ recognized the customary law basis of the principles of non-use of force and non-intervention as evidenced by both state practice and opinion juris, and stated that:

The principle of non-intervention involves the right of every sovereign State to conduct its affairs without outside interference; though examples of trespass against these principles are not infrequent, the Court considers that it is part and parcel of customary international law. As the Court has observed: 'Between independence States, respect for territorial sovereignty is an essential foundation of international relations' (ICJ Reports 1949, p.35) and international law requires political integrity also to be respected. ${ }^{82}$

After World War II, the tension between sovereignty and human rights in the established international legal order is manifest in the opening words of the United Nations Charter. War is to be renounced as an instrument of national policy and human rights are to be affirmed. Under Article 2(4) of the Charter, the threat or use of force is prohibited and protection of human rights is observed in the provisions of Articles 55 and 56. Chesterman noted that the most recent writers who pay attention to humanitarian intervention recount this tension; ${ }^{83}$ he then proceeds to consider a series of alleged instances of intervention on humanitarian grounds, in order to conclude whether or not such a right exists in practice. ${ }^{84}$

The place of humanitarian intervention in the contemporary modern legal system is a controversial issue among jurists. ${ }^{85}$ Some jurists have doubted the legality of

${ }^{81}$ See the Corfu Channel case, ICJ. Rep. 1949, 4, at 35. See also ibid. at 26-31.

82 See the Military and Paramilitary Activities in and Against Nicaragua (Nicaragua v. United States) Jurisdiction and Admissibility, ICJ. Rep. 1984, at 392, para. 85; 429, para. 79; 431, para. 90; 432, para. 93; 433-434, para. 94; 434.

${ }^{83}$ See Chesterman, n. 18, at 45.

${ }^{84}$ Ibid.

${ }^{85}$ See E. Borchard, The Diplomatic Protection of Citizens Abroad, New York Banks Law, 1922. See also L. Oppenheim, International Law, Vol. 2 ( $7^{\text {th }}$ edn., ed by H. Lauterpacht), London, 1948; H. Lauterpacht, "The Grotian tradition in international law", 23 BYIL (1946); id., International Law and Human Rights, London: Stevens and Sons, 1950; J.L. Brierly, The Law of Nations: An Intro- 
the doctrine as part of modern international law and attempted to reject it on a number of legal and moral grounds. Waldock, for example, doubted the doctrine's legitimacy because "its basis was [possibly] sheer power rather than law." ${ }^{66}$ It has also been claimed that the principle is supported simply as the ultimate sanction against human rights violations, thus as the only means of enforcing an international minimum standard. The argument was used to allow the temporary or permanent substitution of sovereign rule in the "offending" state, "in the name of the society of nations", a collective rather than unilateral endeavour in the $1920 \mathrm{~s} .{ }^{87}$ In regard to the status of the doctrine of humanitarian intervention, Lauterpacht pointed out that:

There is a substantial body of opinion and practice in support of the view that ... when a state renders itself guilty of cruelties against and persecution of its nationals in such a way as to deny their fundamental human rights and to shock the conscience of mankind, intervention in the interest of humanity is legally permissible. ${ }^{88}$

Lauterpacht, however, states that this doctrine "has never become a fully acknowledged part of positive international law", 89 and admits that it is, in fact, a "precarious doctrine". 90

\section{INTERVENTION FOR THE PROTECTION OF HUMAN RIGHTS}

The idea of intervention for the protection of human rights dates back to the seventeenth century when some writers, namely Grotius, ${ }^{91}$ Vattel $^{92}$ and Wolff,,${ }^{93}$ began to consider the validity of intervention by a state in the affairs of another for the protection of those rights. Grotius, on the one hand, admitted that a state's form of Government was its own concern, but on the other hand he supported action taken by other rulers in the affairs of other states. ${ }^{94}$ He stated that:

\footnotetext{
duction to the International Law of Peace ( $6^{\text {th }}$ edn. ed. by H. Waldock), Oxford: Clarendon Press, 1963.

${ }^{86}$ See Waldock, n. 1, at 403. See also Brierly, n. 85.

87 See Borchard, n. 84, at 14.

${ }^{88}$ See Oppenheim, n. 85, at 279.

${ }^{89}$ See Lauterpacht, "The Grotian tradition in international law", n. 85, at 46.

90 See Lauterpacht, International Law and Human Rights, n. 85, at 31-32.

${ }^{91}$ See Grotius, Bk. II, Ch. XXV, sect. 8.

${ }_{92}$ See n. 16.

${ }^{93}$ See n. 14.

${ }^{94}$ Grotius in regard to punitive war supported civilized government intervention in the affairs of other States. At the beginning of the twentieth century, Theodore Roosevelt along the lines of Grotius supported intervention as a police measure. He stated that "[c]hronic wrongdoing, or an impotence which results in general loosening ties of civilized society, may in America, as elsewhere, ultimately require intervention by some civilized nation, and in the Western Hemisphere the adherence of the United States to the Monroe doctrine may force the United States, however, reluctantly, in flagrant cases of such wrongdoing or impotence, to the exercise of an international police power". Cited
} 
If a tyrant ... practises atrocities towards his subjects which no just man can approve, the right of human social connection is not cut off in such a case ... Constantine took arms against Maxentius and Lucius; and several of the Roman Emperors took or threatened to take arms against the Persians if they prevented not the Christians from being persecuted on account of their religion. ${ }^{95}$

Vattel confirmed intervention in the affairs of other states for the protection of human rights in the following manner:

[I]f a prince by violating the fundamental laws, gives his subjects a lawful cause for resisting him, if by his un-supportable tyranny, he brings on a national revolt against him, any foreign power may rightfully give assistance to an oppressed people who ask for aid ... foreign nations may assist one of the two parties which seems to have justice on its side. ${ }^{96}$ (emphasis added)

The idea of protection of certain fundamental rights by sovereign states, which was propagandized by those writers, eventually appeared in the behaviour of some states in the form of important provisions in their respective constitutions and other national instruments. The Habeas Corpus Act and the Petition of Rights Act in 1679, the Bill of Rights in 1689, and the French Declaration of the Rights of Man and Citizen are good examples. Later, the collective protection of the rights of minorities was asserted in and exercized through bilateral and multilateral treaties which gave the right to groups of states to interfere in the affairs of another state failing to observe guarantees undertaken by it. Such treaties gave to the collective system the right of intervention in the affairs of other states for safeguarding the human rights of minorities. The basic criterion of these treaties remained the protection of religious or ethnic minorities.

During the seventeenth century, various treaties were undertaken for the protection of Catholic minorities living in states with Protestant majorities. An important landmark for the protection of a religious minority living within the territory of other states was the Treaty of Westphalia in 1648. Parties undertook to protect the rights of their respective subjects forming religious minorities on parity with the majority. ${ }^{97}$ Following the Treaty of Westphalia for the protection of the religious minorities living in states with another majority religion, other treaties were and established, such as the Treaty of Velau (Wehlau) between Poland and Brandenburg in $1657,{ }^{98}$ the Treaty of Peace among Poland, Austria, Sweden and Brandenburg in $1660,{ }^{99}$ and the Treaty of Nijmegen between the Holy Roman Empire and France in $1679 .{ }^{100}$ For the pro-

\footnotetext{
in Chesterman, n. 18, at 36-37.

95 See Grotius, n. 91, II, Ch. XXX, sect. 8.

96 See Vattel, n. 16, II, Ch. IV, 56.

97 See De Lima, n. 15, at 104-106.

98 Ibid.

99 Ibid.

100 Ibid.
} 
tection of Christians living in the Ottoman Empire, few treaties undertaken by European states ${ }^{101}$ gave the signatories to the respective treaties the right to intervene, in concert or individually, in the affairs of the guaranteeing power, in response to the non-observance of the undertaking. ${ }^{102}$ The protection of these rights in practice, however, remained chiefly the concern of the powerful states when these states met at the crossroads of power, the main issue was mostly allowed to go into abeyance. The protection of such rights acquired under treaty provisions, after the end of the First World War, became the chief concern of the League of the Nations. The Principal and Associated Powers concluded a series of treaties with Poland, Czechoslovakia, the Serb-Croat-Slovene state, Romania, Greece, Austria, Bulgaria, and Hungary in order to safeguard the rights of minorities by giving them equal treatment to that accorded to the rest of their populations. ${ }^{103}$ The general pattern of these treaties was that all the inhabitants of these states were accorded full and complete protection of life, liberty and free exercise of creed, religion or belief. ${ }^{104}$

In the League Covenant, the protection of human rights appears only in the provision regarding the mandate territories, which was a result of pre-League experience, such as the treaty rights obtained from Turkey to protect the rights of the Christians. The League of Nations, as evidenced, became the guarantor for the application of the terms of the minority treaties. In this sense the League replaced the powers that intervened to protect minority rights, ${ }^{105}$ individually or collectively, as expediency demanded. ${ }^{106}$

The protection of human rights has been keenly debated in the United Nations. Therefore, the UN Charter has made considerable reference to the promotion of these rights on a universal scale and they are mentioned repeatedly throughout the Charter, unlike in the League Covenant where human rights were protected in the mandated territories only. Art 1 (3) provides for the co-operation of the member states to realize certain fundamental human rights. It referred to "promoting and encouraging respect

101 The treaty gave Russia the right to intervene in the affairs of Turkey in the case of denial of the rights of Christians. The first collective intervention to protect a treaty right took place in 1827 when Turkey failed to protect the rights of Greek Orthodox Christians. Russia started the Crimean War under the terms of the Treaty of Kutchuk-Kainardji. See n. 15, at 104-106.

102 See H. Rosting, "Protection of minorities by the League of Nations", 17 AJIL (1923), at 641.

103 Ibid.

104 Ibid.

105 For more details about protection of minority at that time, see M.K. Ganji, International Protection of Human Rights, Paris: Minard Press, 1962; H. Kelsen, Principles of International Law ( $2^{\text {nd }}$ edn. ed. by R. W. Tucker), New York, etc.: Holt, Rinehart and Winston, Inc., 1966.

106 See the Polish Treaty on 28 June 1919, partly quoted in 17 AJIL. For the protection of minority rights, Article 12 of the Treaty states that: "Poland agrees that the stipulations in the foregoing Articles, so far as they affect persons belonging to racial, religious, or linguistic minorities, constitute obligations of international concern and shall be placed under the guarantee of the League of Nations. ... any member of the Council of the League of Nations shall have a right to bring to the attention of the Council any infraction or any danger of infraction of any of these obligations, ... the Council thereupon take such action and give such direction as it may deem proper and effective in the circumstances." 
for human rights and for fundamental freedoms for all without distinction". Article 55 (c) repeats the same principle in general terms and calls for "universal respect for, and observance of, human rights and fundamental freedom for all without distinction as to race, sex, language, or religion". Article 76(c) also emphasises this point and asserts an aim: "to encourage respect for human rights and for fundamental freedoms for all without distinction as to race, sex, language, or religion, and encourage recognition of the interdependence of the people of the world".

Here, this question may arise: do the UN Charter provisions on human rights create mandatory obligations of a legally binding character? The legally binding character of the provisions of the Charter on human rights is a controversial question among jurists. In this regard, among authorities on international law various opinions are observed, which can be divided into two categories. The first school of thought, represented by scholars such as Lauterpacht ${ }^{107}$ and Jessup, ${ }^{108}$ is that the UN Charter provisions on the human rights issue have created "mandatory obligations" of a legally binding character. Lauterpacht emphasized the "mandatory obligations" and referred to Article 13 of the UN Charter, which provides that the Assembly shall make recommendations for the purpose of assisting in the realization of human rights and freedoms. ${ }^{109} \mathrm{He}$ also cited Article 55 (c) of the UN Charter which requires "universal respect for, and observance of, human rights and fundamental freedoms" and Article 56, which states that "all members pledge themselves to take joint and separate action in co-operation with the organization for the achievement of the purposes set forth in Article 55". ${ }^{110}$ On the other hand, Kelsen in his work, The Law of the United Nations, ${ }^{111}$ rejects the "mandatory obligations" 112 and argues that Charter provisions are only in the nature of declarations and goals to be realized and are, at most, "imperfect obligations" without any binding force. ${ }^{113} \mathrm{He}$ argues that the Charter provisions do not impose upon the members a strict obligation to grant to their subjects the rights and freedoms mentioned in the Preamble or the text of the Charter. ${ }^{114}$

It seems that there are three main reasons why the UN Charter provisions on the human rights issue are deemed not to have created "mandatory obligations" of a legally binding character:

107 See Lauterpacht, International Law and Human Rights, n. 85, at 148.

108 See P.C. Jessup, A Modern Law of Nations, ( ${ }^{\text {rd }}$ edn.), New York: Macmillan Press, 1949, at 87-92.

109 See Lauterpacht, International Law and Human Rights, n. 85, at 148.

110 Ibid.

111 See H. Kelsen, The Law of the United Nations, London: Stevens and Sons, 1950. See also id., "Collective security and collective self-defence under the Charter of the United Nations", 42 AJIL (1948).

112 Ibid., at 29.

113 Ibid.

114 Ibid. 
- First, the language of the UN Charter does not support the interpretation that the Members are under a legal obligation regarding the rights and freedoms of their subjects. All the formulae concerned establish the purposes or functions of the Organization, not the obligations of Members, and the Organization is not empowered by the Charter to impose upon the governments of Member states the obligation to guarantee their subjects the rights referred to in the Charter. Lauterpacht has referred to Articles 13, 55 and 56 of the UN Charter as evidence for "mandatory obligations", but the language used in those articles does not lend itself to this kind of interpretation. Article 13, for example, requests that the General Assembly initiates studies and makes recommendations for the purpose of promoting international co-operation in the political, economic, and cultural fields, and assisting in the realization of human rights and fundamental freedoms. Clearly, those recommendations cannot create "mandatory obligations", because UN provisions do not impose upon the Members a strict obligation to obey them. ${ }^{115}$

- Secondly, supporting the idea of the legally binding character of the provisions of the Charter on human rights would give rise to anarchy in the international community, which would certainly not achieve the main purposes of the UN Charter. Indeed, the lack of clear criteria for the concept of human rights would allow states to interfere in the behaviour of others in the name of human rights when motivations other than human rights were involved, as we have seen on some occasions, such as the intervention of the US in Grenada in $1983^{116}$ and in Panama in 1989. ${ }^{117}$ There were few interventions solely for human rights, such as the intervention of the US in Rwanda, which the present author does not want to ignore. There were, however, many cases in which states interference in the behaviour of others in the name of human rights when motivations other than human rights were involved.

- Thirdly, the history of Articles 55 and 56 of the UN Charter shows that none of the delegates made any direct statement about mandatory obligations. The short historical review of Article 55 of the UN Charter demonstrates that only during the discussion about the article did a few delegates demand a separate action when grave infringement of basic human rights occurred and co-operation from the states concerned was not forthcoming. However, they emphasized that the International Organization should take such action in order to protect basic human rights. ${ }^{118}$ It is significant that even the US delegates supported the view

115 The General Assembly shall initiate studies and make recommendations for the purpose of: “... b. promoting international co-operation in the economic, social, cultural, educational, and health fields, and assisting in the realization of human rights and fundamental freedoms for all without distinction as to race, sex, language, or religion." UNCIO, Vol. X. at 340. UNCIO. Vol. VI, at 439.

116 UNYB, 1983, at 211. See General Assembly Resolution 38/7 (1983), para. 1.

117 UNYB, 1989, at 175. See General Assembly Resolution 44/20 (1989).

118 See the view of the representative of the former Soviet Union during the discussion on Article 56. UNCIO, Vols. 6 and 10. See also the view of the Australian delegate in the course of the drafting of the provisions of the application of the enforcement measures under Chapter VII as an exception 
that, in such a case, only the International Organization could intervene in domestic affairs, even though unilateral interventions by the United States in the course of time proved that there is a serious discrepancy between theory and reality in the US policy.

At the San Francisco Conference on International Organization, those delegates certainly intended to authorise only the International Organization, in extreme circumstances, to intervene in the case of grave infringements of basic human rights by a state, in order to prevent such infringements; unilateral armed intervention by states for the protection of human rights had no place at that time.

Attempts to justify incidents of the unilateral intervention of states in the affairs of another state for the protection of human rights in some circumstances have been seen by scholars as based on legal or moral arguments. They presented different arguments for the same aim - protecting innocent people - which in this paper will be divided into three categories.

\subsection{Intervention under a higher ranking law}

The advocates of the first category argue that if the lives of people are at stake, the formal law ought to be violated to save thousands of lives to achieve the higher goal, even if the Security Council does not authorize force. ${ }^{119}$ This is a view of some scholars who consider humanitarian intervention to be a moral imperative. ${ }^{120}$ They note that the identification of human rights, and the protection of the inherent dignity

to the general rule of non-intervention by the Organization in the domestic jurisdiction over human rights, who called the fundamental freedoms a matter of international concern and as such not falling within the "essentially" domestic jurisdiction of the state concerned. In a comment on the issue, the Australian representative pointed out that "... the clause in its wide form is needed in order to enable the Security Council to deal with grave infringements of basic rights within a state".

119 Some politicians including the Czech President in the light of the human tragedy in the Balkans in the final decade of the twentieth century have chosen a different approach to the question of the "territorial integrity and political independence of states". They refer to NATO air strikes against Serbia in 1999 and argue that, even though NATO acted with no authority from the UN Security Council, this violation of the UN Charter did not constitute an act of aggression or disrespect for international law, but took place under another law (human rights), one that ranks higher than the law which protects the sovereignty of states. In their view, to breach and ignore the territorial integrity and political independence of states in order to protect human life is permissible and applicable in many cases. If this view is accepted, however, there is no respect left for Article 2 (4). The phrase "territorial integrity and political independence" has been the object of controversy as to its meaning in relation to the prohibition of the use of armed force in Article 2(4) of the Charter.

120 See A. Cassese, "Ex iniuria ius oritur: are we moving towards international legitimation of forcible humanitarian countermeasures in the world community?", 10 EJIL (1999), at 25. See also id., "A follow-up: forcible humanitarian countermeasures and opinio necessitates", 10 EJIL (1999); A.D. D'Amato, "The invasion of Panama was a lawful response to tyranny", 84 AJIL, 1990, at 516-520; id., International Law: Process and Prospect, New York: Transnational Publishers, 1987. 
and equality of all members of the human family, are acknowledged in the Universal Declaration of Human Rights (UDHR) and UN Charter. Hyndman, for example, asserts those purposes and states that they "are essential prerequisites for true and firm foundations for freedom, justice and peace in the world." ${ }^{121}$ In this regard, the editors of Oppenheim, Jennings and Watts, also argued that involvement of the international community on both a global and a regional basis "with the protection of human rights diminishes any need for states to retain or exercise an individual right of humanitarian intervention." 122 Oppenheim stressed that "if humanitarian intervention is ever to be justified, it will only be in extreme and very particular circumstances." 123

In regard to the legality of humanitarian intervention, advocates claim that unilateral force is permitted to enforce the human rights provisions in the Charter. Since promotion of human rights is one of the primary purposes of the Charter, then the use of force to compel compliance would not violate Article 2(4) of UN Charter. This claim is not for enforcement, but for the "self-enforcement" of human rights provisions. It is precisely the argument favouring humanitarian intervention as a unilateral right. This argument ignores the possibility that force to uphold human rights might be inconsistent with the maintenance of peace. It even requires the assumption that the intervenor has ascertained the true wishes of the people, is willing to effect these wishes, and does so without violating the state's integrity and independence. Here, also this question was propounded: does it imply that every single UN purpose stated in Article 1 of the Charter can be pursued through the unilateral use of force? Clearly, the unilateral use of force has no place in this respect. In the current international legal system, collective security, which has the character of enforcement action on behalf of the international community, fulfils a general interest shared by all states. It has been entrusted to the United Nations through the SC, which has the primary responsibility for the maintenance of international peace and security, and through the GA by virtue of the 'Uniting for Peace' Resolution. ${ }^{124}$ Therefore, it is correct to say that under modern international law, the unilateral use of force for maintaining international peace and security, as well as for vindicating international law, is inadmissible. The reactions of some states against the UK and French Governments' ultimatum over the 1956 Suez crisis and NATO in the 1999 Kosovo crisis demonstrate this fact. In the former case, following the Israeli aggression over the Suez Canal on 26 October 1956, the UK and French Governments issued a joint ultimatum and demanded the cessation of hostilities and withdrawal of the forces of both belligerents from the Canal. ${ }^{125}$ The ultimatum also demanded the temporary

\footnotetext{
121 Hyndman, "Sri Lanka: a study in microcosm of regional problems and need for more effective protection of human rights", 20 DJILP (1992), at 303.

122 See 1 Oppenheim's International Law ( $9^{\text {th }}$ edn. ed. by Jennings and Watts), Longman Group Ltd, 1992, at 443-444.

123 Ibid.

124 GA Res. 377 A (v) (1950).

125 See S/3712, SCOR, $11^{\text {th }}$ yr. Suppl. October-December 1956, at 11.
} 
occupation of certain key positions of the Canal area on Egyptian territory by the UK and French forces. ${ }^{126}$ It also threatened that:

Failing an answer by 6:30, Cairo time, on 31 October 1956, the Governments of the UK and France would intervene in whatever strength they might deem necessary to secure compliance. ${ }^{127}$

The legal status of the ultimatum was discussed and rejected by many states, including the US. Among the arguments the statements of the representatives of Yugoslavia and the US were remarkable. The representative of Yugoslavia stated that:

While the Security Council, the organ of the United Nations which bears primary responsibility for the maintenance of peace and security, is considering the action to be taken in the face of Israel aggression against Egypt, two Member States of the United Nations have apparently decided to embark upon what can be described as the unilateral application of force. They have done so clearly without any kind of authorization from the United Nations. ${ }^{128}$

The representative of the US also emphasized that his government believed that if the draft resolution were adopted and promptly carried out, the reason for the twelvehour United Kingdom and French ultimatum would be invalid as its basis would have disappeared. ${ }^{129} \mathrm{He}$ further concluded that "we do not imply that in any circumstances this ultimatum would be justifiable or be found to be consistent with the purposes and principles of the Charter."

Following the collapse of the Rambouillet negotiations ${ }^{131}$ (in France on 29 January 1999, co-chaired by the UK and France) between the Kosovo Liberation Army (KLA) and the Federation Republic of Yugoslavia (FRY) in the middle of March, air strikes were launched on 24 March 1999, and continued for 78 days by NATO. The action

\footnotetext{
126 Ibid.

127 Ibid. The representative of the UK in the Security Council, Mr Pierson Dixon, tried to justify the objective of the Anglo-French action for stopping the fighting and safeguarding the free passage of shipping through the Suez Canal in the general interest and in the interest of security and peace. SCOR, $11^{\text {th }}$ yr., $749^{\text {th }}$ mtg., para 11.

128 SCOR $11^{\text {th }}$ yr., $749^{\text {th }}$ mtg., para. 25 .

129 Ibid., para. 22.

${ }^{130}$ Ibid.

131 The first round of negotiations in Rambouillet started from 6 to 23 February 1999, followed by a second round in Paris, from 15 to 18 March 1999. The proposed settlement at Rambouillet, dictated by the West, required: Yugoslavia to withdraw its forces from Kosovo, the KLA to lay down their arms, NATO peace-keeping troops on the ground to enforce the agreement, and a threeyear period to settle the political future of Kosovo. See H. McCoubrey, 'Kosovo, NATO and international law', 14 International Relations (August 1999), at 31-38.
} 
met with the strong opposition of some states, ${ }^{132}$ including two permanent members of the SC, Russia and China, who believed the UN Security Council had not authorized military action against Serbia. They raised considerable objections to NATO's action. ${ }^{133}$ Universal condemnation of the joint Anglo-France action in Suez that purported to restore international peace and security in the area by unilateral means, and considerable objections to NATO's action in Kosovo, demonstrated these objections. Therefore, it can be said that no purpose of the UN can be realized by resort to the unilateral use of force.

\section{Intervention as an ethical obligation}

The second category of our study concerns those people whose support of humanitarian intervention is based on an ethical viewpoint. Since the international community has witnessed mass violations of human rights in the late twentieth century, a few scholars such as Cassese rely on the ethical viewpoint; they argue that unilateral intervention without Security Council authorization in order to stop such violation is, in extreme circumstances, permissible, even though it is contrary to the UN Charter. ${ }^{134}$ Cassese in his work, "Ex iniuria ius oritur: Are We Moving towards International Legitimization of Forcible Humanitarian Countermeasures in the World Community?" tries first, to demonstrate the place of human rights in the present world ${ }^{135}$ second, seeks to justify NATO action in Kosovo, and third, expresses his support for similar cases in the future. He, as a prominent example of this school, refers to the massacres and other Serb violations in Kosovo; Cassese then argues that resort to armed force may become justified under certain strict conditions, even in the absence of any authorization by the Security Council. ${ }^{136}$ Next, he poses these questions: "Should one sit idly by and watch thousands of humans being slaughtered or brutally persecuted? ${ }^{137}$ Should one remain silent and inactive only because the

\footnotetext{
132 See R.G.C. Thomas, "NATO and international law", May 1999, at http://jurist.law.pitt.edu/ thomas.htm. Available in October 2000. See also McCoubrey, n. 131, at 32-34.

133 Apart from Russia and China, some other states expressed opposition. Among them, the representative of India to the Security Council well expressed his objection to NATO's act. He emphasized that this attack directly violated Article 53 of the Charter, and stated that "No country, group of countries or regional arrangement, no matter how powerful, can arrogate to itself the right of taking arbitrary and unilateral military action against others. That would be a return to anarchy where might is right .... The attacks now taking place on Yugoslavia have not been authorized by the Council, acting under Chapter VII, and are therefore completely illegal." Ibid.

134 See Cassese, "Ex iniuria ius oritur...", n. 120, at 25-27. It should be noted that many years ago, such human tragedy happened in Bosnia and Kosovo. Nardin accepts and supports this position. See T. Nardin, Law, Morality, and the Relations of States, Princeton: Princeton University Press, 1983, at 93-94.

${ }^{135}$ In regard to the place of human rights in the present world he says, "human rights are increasingly becoming the main concern of the world community as a whole. There is a widespread sense that they cannot and should not be trampled upon with impunity in any part of the world." See n. 120 .

136 Ibid.

137 Ibid.
} 
existing body of international law proves incapable of remedying such a situation? ${ }^{138}$ Or, rather, should respect for the Rule of Law be sacrificed on the altar of human compassion?". 139

In order to answer those questions, he argues that resort to armed force was justified from an ethical viewpoint, though this moral action is contrary to the current international legal system. ${ }^{140}$ Then, Cassese introduces the criterion of extreme circumstances in order to prevent misuse of the concept of human rights, as follows:

i gross and egregious breaches of human rights involving loss of life of hundreds or thousands of innocent people, and amounting to crime against humanity, are carried out in the territory of sovereign State, either by the central governmental authorities or with their connivance and support, or because the total collapse of such authorities cannot impede those atrocities;

ii if the crime against humanity results from anarchy in a sovereign state, proof is necessary that the central authorities are utterly unable to put an end to those crimes, while at the same time refusing to call upon or to allow other states or international organizations to enter the territory to assist in terminating the crimes. If, on the contrary, such crimes are the work of the central authorities, it must be shown that those authorities have consistently withheld their co-operation from the United Nations or other international organizations, or have systematically refused to comply with appeals, recommendations or decisions of such organizations;

iii the Security Council is unable to take any coercive action to stop the massacres because of disagreement among the Permanent Members or because one or more of them exercises its veto power. Consequently, the Security Council either refrains from any decision or only confines itself to deploring or condemning the massacres, plus possibly terming the situation a threat to the peace;

iv all peaceful avenues which may be explored consistent with the urgency of the situation to achieve a solution based on negotiation, discussion and any other means short of force have been exhausted, notwithstanding which, no solution can be agreed upon by the parties to the conflicts;

$\mathrm{v}$ a group of states (not a single hegemonic Power, however strong its military, political and economic authority, nor such a Power with the support of a client state or an ally) decides to try to halt the atrocities, with the support or at least the non-opposition of the majority of Member States of the UN;

vi armed force is exclusively used for the limited purpose of stopping the atrocities and restoring respect for human rights, not for any goal going beyond this limit and purpose. Consequently, the use of force must be discontinued as soon as this purpose is attained. Moreover, it is axiomatic that use of force should be commensurate with and proportionate to the human rights exigencies on the ground. The more urgent the situation of killings and atrocities, the more intensive 
and immediate may be the military response thereto. Conversely, military action would not be warranted in the case of a crisis which is slowly unfolding and which still presents avenues for diplomatic resolution aside from armed confrontation. ${ }^{141}$

The present author completely agrees with Cassese that, nowadays, the international community cannot view mass violations of human rights as being acceptable merely because the Security Council is unable to take any coercive action to stop them; failure on the part of the SC to halt them may be as a result of disagreement among its Permanent Members or exercises of veto power. My concern is, however, that Cassese's criteria could all too easily be broadly interpreted by certain superpowers and in the end misapplied to military intervention in the name of human rights, even though Cassese, in his categories, tries to introduce the criterion of extreme circumstances specifically in order to prevent such misuse of the concept of humanitarian intervention. In his final conditions, Cassese argues for example that "armed force is exclusively used for the limited purpose of stopping the atrocities and restoring respect for human rights", yet he ignores the fact that different people approach the concept in different ways. "Respect for human rights" is a principle accepted and confirmed by all human beings, but there are different interpretations of this "respect". There are many concepts such as violence, pacifism, human rights, freedom, reform, and democracy that can be and are interpreted in different ways. It is not the purpose of this work to enter into discussion, but I wish only to remind readers of this difference by offering an example. As we know, violence against human beings is seen as wrong from the pacifist point of view. In this regard, some pacifist philosophers ${ }^{142}$ renounce all types of violence absolutely, and support the absolutist position. ${ }^{143}$ Others, ${ }^{144}$ however, reject only certain types of organized violence, such as warfare and violent revolution. ${ }^{145}$ As we have seen, the concept of pacifism is defined in different ways amongst its philosophers. Therefore, how is it possible that the military intervention of states in the internal affairs of others be offered through reasons of "respect for human rights?" There is no consensus on some concepts, such as "respect for human rights." It is hard to accept unilateral intervention, without authorization from the Security Council, simply by invoking respect for human rights.

\footnotetext{
141 Ibid.

142 See J. Meyerding, "Feminism and pacifism: doing it our way", WIN (October 1979), at 10.

143 See the argument of J. Meyerding, as one of the absolutist pacifists. She rejects all forms of violence and defines all kinds of violence in this manner: "Pacifism is opposed to violence in all forms, including physical, emotional, intellectual, and economic coercion ... because violence denies the value of its victims' lives." Ibid.

144 See G. Sharp, Gandhi as a Political Strategist: With Essays on Ethics and Politics, Boston: Porter Sargent, 1979, at 205-206. See also G. Sharp, Social, Power and Political Freedom, Boston: Porter Sargent, 1973.

145 G. Sharp supports this idea and defines pacifists as "those persons and groups who, as the minimum, refuse participation in all international or civil wars or violent revolutions, and base this refusal on moral, ethical, or religious principle." Ibid.
} 
The concept of human rights also has often been used as a pretext for unilateral armed intervention by major powers in other states. The intervention of the US in the name of human rights in Nicaragua is a prominent example. In this intervention the US destroyed certain economic resources of the Sandinista Government, in order ostensibly to protect human rights. The ICJ in the Nicaragua Case clearly did not accept the US's argument and ruled:

[W]here human rights are protected by international conventions, that protection takes the form of such arrangements for monitoring respect for human rights as are provided for in the conventions themselves. ${ }^{146}$

[T] the use of force could not be the appropriate method to monitor or ensure such respect. With regard to the steps actually taken, the protection of human rights, a strictly humanitarian objective, cannot be compatible with the mining of ports, the destruction of oil installations, or again, with the training, arming and equipping of the contras ... (emphasis added). ${ }^{147}$

Nowadays the view prevails, particularly amongst developing countries, that humanitarian intervention may be a pretext for intervention by major powers for political purposes or motivations other than human rights protection. Mani rightly says "a cursory look at the history of international relations is enough to reveal that the "facility" of intervention has been repeatedly utilized by big powers against small powers." "148 Therefore, it is true to say that the history of most interventions in the past created a fear of abuse, in the view of the international community. Frank and Rodley well demonstrated the fear in this manner:

When States wish to intervene, they will reach for convenient humanitarian justifications that extend from genocide to electoral irregularities. When nations wish to avert their eyes, even millions dying in concentration camps or under the treads of tanks are perceived as merely local problems to be left to those in charge, often by States which have themselves pleaded the right of humanitarian intervention in other instances. $^{149}$

\subsection{Intervention for human rights and Article 2(4)}

The final group of our study in this paper is supported by Anthony D'Amato ${ }^{150}$

146 ICJ. Rep. 1986, at 134, para 267.

147 Ibid., at 134-5, para 268.

148 See V.S. Mani, "Humanitarian intervention and international law", Ind.JIL (1996), at 25.

149 See T. Frank and Nigel Rodley, "After Bangladesh: the law of humanitarian intervention by military force', 67 AJIL (1973), at 294.

${ }^{150}$ D'Amato advocates a restricted sense of Article 2(4) of the Charter and permits limited intervention. Despite the clear intention of States Parties to the San Francisco Conference, including the United States delegate, who emphasized that there were "no loopholes in the provisions", 
and Fernando Teson. ${ }^{151}$ They argue that humanitarian intervention on the basis of the protection of human rights is not a violation of the "territorial integrity and political independence" of the target state. ${ }^{152}$ They support a restricted sense of Article 2(4) of the Charter and then present the idea that a war waged in a good cause would violate neither the territory integrity nor the political independence of the state. Teson, for example, argues that genuine humanitarian intervention does not result in territorial conquest or political subjugation. ${ }^{153}$

In order to respond to the claims of those writers who have argued that forceful humanitarian intervention does not comprise force against the territorial integrity or political independence of the target state, it is submitted that the military intervention of one state against another state on humanitarian grounds is directly opposed to the territorial integrity of states, as we have seen in many cases such as the Indian intervention in East Pakistan/Bangladesh in $1971 ;{ }^{154}$ the Vietnamese intervention in Cambodia in 1978; ${ }^{155}$ the Israeli intervention in Uganda in $1976 ;{ }^{156}$ the Belgian and French intervention in Zaire in $1978 ;{ }^{157}$ the Tanzanian interventions in Uganda in $1978^{158}$ and $1979 ;^{159}$ the US intervention in Granada in $1983 ;^{160}$ the US intervention in Panama in 1989-90, ${ }^{161}$ and finally, the NATO intervention in Kosovo in 1999; these culminated in the territorial violation of Pakistan, Cambodia, Uganda, Zaire, Granada, Panama, and Serbia, respectively.

D'Amato, after examining the travaux preparatoires of the article, argues that the delegates to the San Francisco Conference simply did not understand the words they were using. Later he also claimed that the US invasion of Panama in 1989 complied with Article 2 (4) because the US did not intend to, and has not, colonialized, annexed or incorporated Panama. See A. D'amato, "The invasion of Panama was a lawful response to tyranny", n. 120, at 516-520.

151 See F.R. Teson, Humanitarian Intervention: An Inquiry into Law and Morality, $22^{\text {nd }}$ edn., New York: Transnational Publishers, 1997, at 150.

152 See D’Amato, International Law: Process and Prospect, n. 120, at 57-70.

153 See Teson, n. 116, at 151.

154 S/PV.1606 (1971), para 186. GA Res. 2793 (XXVI) (1971), paras. 4 \& 8. SC Res. 303 (1971). See also D.W. Bowett, "The use of force for the protection of nationals abroad", in A. Cassese (ed.), The Current Legal Regulation of the Use of Force, Dordrecht: Martinus Nijhoff, 1986.

155 See T. Avirgan and Martho Honey, War in Uganda: the Legacy of Idi Amin, Westport: Lawrence Hill, 1982. See also Vietnam's Intervention in Cambodia in International Law, Canberra: AGPS, 1989.

156 For more details see S/PV. 1939 (1976), paras. 106-15; S/PV. 1941 (1976), para. 77; S/12139 (1976).

157 See Chesterman, n. 18, at 76-77.

158 Ibid.

159 Ibid.

160 UNYB (1983), at 211. The Security Council failed to protest the intervention only by reason of a US veto. In this regard the General Assembly adopted resolution 38/7 in 1983 and emphasized that it deeply deplore[d] the intervention as a flagrant violation of international law. See para 1. 161 UNYB (1989), at 175. Again, a Security Council resolution was blocked by veto. The General Assembly in this regard adopted the resolution by an overwhelming majority and condemned the unilateral action by the US. See GA Res. 44/20 (1989). 
Again, the military intervention of one state in the affairs of another state on humanitarian grounds is directly opposed to the notion of the territorial integrity of states. In the case of Pakistan, the Indian action resulted in the secession of the Eastern Province, that is, in the permanent territorial impairment of the country. In the cases of Cambodia and Uganda, it resulted in the violent overthrow of the Government of each of these countries. It may thus be questioned what indeed constitutes force against the territorial integrity or political independence of a state, if the above instances are not seen as doing so. Our claim is supported by states of the General Assembly Declaration on Friendly Relations, ${ }^{162}$ Security Council and General Assembly resolutions, ${ }^{163}$ and ICJ decisions ${ }^{164}$ which concern the meaning of nonintervention and condemnation of the unauthorized use of force by a state.

Moreover, the UN Charter is a multilateral treaty and is therefore subject to many of the same customary law rules of interpretation as are other treaties. The Vienna Convention on the Law of Treaties, ${ }^{165}$ now applied as custom by ICJ in the Maritime Delimitation and Territorial Questions case (Qatar/Bahrain), ${ }^{166}$ provides that "A treaty shall be interpreted in good faith in accordance with the ordinary meaning to be given to the terms of the treaty in their context and in the light of its object and purpose". ${ }^{167}$ Therefore, such an interpretation of Article 2(4) is unreasonable as it directly ignores the aim of the article.

\section{INTERVENTION AND STATE PRACTICE}

State practice does not support the existence of unilateral intervention in the light of the humanitarian intervention doctrine. A quick look at the Indian intervention in East Pakistan and the Vietnamese intervention in Cambodia has shown that representatives of third states did not support those actions, even though both states tried to justify their actions in humanitarian terms. Regarding the Indian intervention in East Pakistan, the international community not only did not accept its action and argument, which emphasized "the purest of motives and the purest of intentions: to rescue the people of East Bengal from what they are suffering", ${ }^{168}$ but also urged

\footnotetext{
162 See GA Res. 2625 (XXV) (1970).

163 See GA Res. 45/150 (1990); 2625 (1970).

164 See the Corfu Channel case, ICJ. Rep. 1949, 4, at 35. See also ibid. at 26-31. Military and Paramilitary Activities in and Against Nicaragua (Nicaragua v. United States), Jurisdiction and Admissibility, ICJ. Rep. 1984, at 392, para. 85; 429, para. 79; 431, para. 90; 432, para. 93; 433-434, para. 94; 434.

165 See Vienna Convention on the Law of Treaties of 1969.

166 ICJ Rep. 1995, 6, at 18, para. 33. Cf. Territorial Dispute (Libyan Arab Jamahiriya/Chad), ICJ. Rep. 1994, 6, at 21-22, para. 41.

167 Article 31 (1).

168 See SCOR, $26^{\text {th }}$ yr., $1606^{\text {th }}$ and $1608^{\text {th }}$ mtgs., paras. 185 and 262 . The Indian representative in the Council, Mr. Sen, made a reference to considerations of humanity as the basis of India's action in East Pakistan. However, India's justification was far from being the central argument for action. During the debate, the point was made repeatedly: "Provocation and aggression of various kinds
} 
India to cease hostilities and withdraw from East Pakistan. ${ }^{169}$ On 25 December 1978, the Vietnamese took military action in Cambodia. As a result of the action the Khmer Rouge Government, which had perpetrated horrific atrocities against the Cambodian population between 1975 and 1978, was overthrown. ${ }^{170}$ The majority of states considered Vietnam's action as unlawful intervention. ${ }^{171}$ In this regard, some representatives expressly indicated their objection against the use of force in order to protect human rights. For example, the representative of Singapore stated that:

No other country has a right to topple the Government of Democratic Kampuchea, however badly that Government may have treated its people. To hold to the contrary principle is to concede the right of a foreign Government to intervene and overthrow the Government of another country.... ${ }^{172}$

The representative of France stated that:

The notion that because a regime is detestable foreign intervention is justified and forcible overthrow is legitimate is extremely dangerous. That could ultimately jeopardize the very maintenance of international law and order and make the continued existence of various regimes dependent on the judgment of their neighbours. ${ }^{173}$

by Pakistan from 25 March onwards is a reality. As a result, retaliation had followed in exercise of the right of self-defence, and we have warned that we shall exercise this right without hesitation". For more details see SCOR, $1680^{\text {th }} \mathrm{mtg}$., para. 272.

169 Ibid., The US representative emphasized that the action is contrary to the UN Charter $\left(1606^{\text {th }}\right.$ mtg., paras. 193-194). See also para. 237 (China), paras. 201-213 (Italy), paras. 220-227 (France), paras. 279-292 (Belgium).

170 As a result of the action, a new Government was formed, composed of Members of a "Cambodian National Front" that appears to have been formed under the patronage of the replacement Vietnamese Government. By that time, relations between Cambodia and Vietnam had been severely strained because of repeated border incidents perpetrated by the Cambodian armed forces since 1975. During the debate at the Security Council the Vietnamese representative pointed out, "In order to draw a clear picture of the problem of Kampuchea, it is appropriate to make a clear distinction between two wars: one, the border war ... against Vietnam, which the Vietnamese people have been forced to deal with; the other, the revolutionary war of the Kampuchean people against the dictatorial rule of the Pol Pot-Leng Sary clique .... Like any other country in a similar situation, Vietnam is determined to exercise its right of legitimate defence recognized by the Charter of the United Nations and by International law in order to defend its independence, sovereignty and territorial integrity."

171 See SCOR, $34^{\text {th }}$ yr., $2109^{\text {th }}$ mtg., para. 18 (Norway); SCOR, 34 ${ }^{\text {th }}$ yr., $2109^{\text {th }}$ mtg., para. 36 (France); SCOR, $34^{\text {th }} \mathrm{yr}, 2110^{\text {th }} \mathrm{mtg}$., para. 49 (Singapore); SCOR, $34^{\text {th }} \mathrm{yr}$., $2110^{\text {th }} \mathrm{mtg}$., paras. $27-29$ (Portugal); SCOR, $34^{\text {th }}$ yr., $2110^{\mathrm{h}} \mathrm{mtg}$., para. 58 (New Zealand). It should be noted that only the former Soviet Union and Czechoslovakia supported Vietnam's action.

172 SCOR, $34^{\text {th }}$ yr., $2110^{\text {th }}$ mtg., para. 49.

173 SCOR, $34^{\text {th }}$ yr., $2109^{\text {th }}$ mtg., para. 36. 
The UK also took the view that:

Whatever is said about human rights in Kampuchea, it cannot excuse Vietnam, whose human rights record is deplorable, for violating the territorial integrity of Democratic Kampuchea, an Independent State Member of the United Nations.... ${ }^{174}$

The US military action without Security Council authorization against Iraq on 3-4 September 1996 met with considerable opposition from many states, ${ }^{175}$ including three of its permanent members: France, ${ }^{176}$ Russia, ${ }^{177}$ and China. ${ }^{178}$ Moscow called the US action "unacceptable" and described the situation as "an inadequate and inadmissible response". ${ }^{179}$ The Kremlin statement also stated that "Russia insists on ending all military actions in Iraq threatening the sovereignty and territorial integrity of that country". ${ }^{180}$ Binyon notes that Moscow, in its statement, used some of the strongest anti-American language since the Cold War. ${ }^{181}$ France, one of the three countries patrolling the no-fly zones, was not satisfied with the action. In this regard a spokesman for its Foreign Ministry affirmed "France's commitment to Iraq's territorial integrity" 182 and noted that "Paris did not believe Saddam had violated United Nations resolutions." 183 Therefore, as Mani says, "under modern international law, there is no place for humanitarian intervention and contrary views in the Western doctrine are untenable in terms of state practice and the ruling of International Court". ${ }^{184}$

\section{CONCLUSION}

The legitimacy and validity of the right of humanitarian intervention is in international law still disputed amongst jurists. Adherents of this doctrine argue that the right survived or emerged after the enactment of the UN Charter and that humanitarian

\footnotetext{
174 SCOR, $34^{\text {th }}$ yr., $2110^{\text {th }}$ mtg., para. 65 .

175 Most Arab nations, apart from Kuwait, strongly condemned the operation. Spain and New Zealand were also concerned that America was acting hastily. Indonesia, the world's most populous Muslim state, regretted the violence.

176 See http://www.the-times.co.uk/cgi-bin/BackIssue? Available in September 2000.

177 The Kremlin in its statement stated: "Russia insists on ending all military actions in Iraq threatening the sovereignty and territorial integrity of that country". See http://www.the-times.co.uk/ cgi-bin/BackIssue? Available in September 2000. See also M. Binyon, "Alarmed Russians call on America to show restraint" in The Times, at http://www.the-times.co.uk/cgi-bin/BackIssue, 4 September 1996. Available in September 2000.

178 Ibid.

179 Ibid. See also http://www.the-times.co.uk/cgi-bin/BackIssue? Available in September 2000.

180 Ibid.

181 See Binyon, n. 177.

182 See n. 177.

183 Ibid.

184 See Mani, n. 148, at 25.
} 
action in Kosovo in 1999 for human rights is compatible with Article 2(4) of UN Charter. However, none of the arguments upon the legitimacy of humanitarian intervention by commentators and politicians - that the right survived or emerged after the enactment of the UN Charter and that recent humanitarian action for human rights is compatible with Article 2 (4) of UN Charter - could be persuasive that it is compatible with the article and purpose of the Charter because:

- The doctrine of humanitarian intervention was repudiated by the ICJ in its judgement in the South-West Africa Case. ${ }^{185}$

- A cursory look at Legality of Use of Force Case in $1999^{186}$ where FRY instituted proceedings against ten NATO members before the ICJ, alleging that their acts were unlawful violations of Article 2(4), reveals, contrary to the claim of NATO leaders, that Counsel in the joint hearings avoided making any reference to humanitarian intervention; instead, Counsel replied that intervention took place in order to protect fundamental values insured in the jus cogens, such as the right to life, ${ }^{187}$ and also to prevent "an impending catastrophe recognized as such by the Security Council". ${ }^{188}$ Apart from the Kingdom of Belgium ${ }^{189}$ which relied on the right of humanitarian intervention before an international tribunal, other NATO members including the UK used the language of Security Council resolution 1199, "humanitarian catastrophe", and did not refer to the humanitarian intervention doctrine. ${ }^{190}$

- State practice does not support the existence of unilateral intervention in the light of the humanitarian intervention doctrine even in the best cases, as discussed in this paper, where intervening states tried to justify their actions in humanitarian terms.

The present legal system does not nowadays recognize the enforcement, by an individual military force, of any claim, except in self-defence because, on the one hand, the text of the Charter contains no express justification of resort to force on humanitarian grounds. Action in self-defence under Article 51 of the Charter cannot be invoked in justifying humanitarian intervention, for there is no necessity of selfdefence on the part of the intervening state. The admissibility of protection of nationals in exercising the right to self-defence is an argument not valid for the protection of the nationals of another state. Indeed, as the international community currently stands, that is, largely composed of sovereign states, the general regime

\footnotetext{
185 See ICJ Rep. 1966, at 6.

186 See Legality of Use of Force (Provisional Measures), ICJ, CRs (1999).

187 Ibid. CR 99/15 (10 May 1999).

188 Ibid.

189 The Kingdom of Belgium took the view that humanitarian intervention is compatible with Article 2 (4). It said, “... Belgium takes the view that this is an armed humanitarian intervention, compatible with Article 2, paragraph 4, of the Charter, which covers only intervention against the territorial integrity or political independence of a state." See Belgium's arguments on the legality of armed humanitarian intervention under the UN Charter in Legality of Use of Force (Provisional Measures), CR 99/15 (10 May 1999).

190 Ibid., CR 99/23 (11 May 1999).
} 
of law on the use of force is applicable exclusively between states. Hence, the right of self-defence is recognized as admissible for the protection of the entirety of a territorial, political and populated community, the state. ${ }^{191}$ Indeed, the claim of the right to use force for the protection of the human rights of the citizens of another state has the difficult task of surmounting the provision of Article 2(4) of the Charter. On the other hand, as we are aware, under the dominant doctrine on the law of state responsibility developed by the UN International Law Commission, the obligation of states to respect and protect the basic rights of all human persons is the concern of all states; that is, they are owed erga omnes. According to the judgment of the Court in the Barcelona Traction case ${ }^{192}$ this duty is owed to entire international communities with regard to certain human rights. Thus, in the event of material breaches of such obligations, every state is obliged to respond to violations, individually and collectively, by the use of non-forcible actions and resort to "countermeasures" against the perpetrator. What does "countermeasures" mean under international law? Does international law permit the use of armed force by foreign states, individually or collectively, to stop violations of international human rights - as some permanent members of the Security Council did in the Persian Gulf in 1996 and Kosovo in 1999? According to modern international law, since 1945, countermeasures must not involve the threat of or use of armed force. This fact was also confirmed in 1970 by the General Assembly's Declaration on Friendly Relations. ${ }^{193}$ Clearly, response to those violations, whether individually or collectively, must be made by states in a non-forcible manner.

It seems that humanitarian intervention by military means is permissible only when mass violations of human rights occurring within a country constitute a threat to peace, as determined by the Security Council, so that the latter finally authorises an enforcement action in order to stop the violations. The ICJ in the Legality of Use of Force case in 1999 reaffirms that "when such a dispute gives rise to a threat to the peace, breach of the peace or act of aggression, the Security Council has special responsibility under Chapter VII of the Charter." 194 Therefore, humanitarian intervention involving the threat or use of military force and undertaken without the mandate or authorization of the Security Council will, as a matter of principle, remain in breach of the UN Charter. Nevertheless, this prohibition of the UN Charter does not mean that the sovereignty of the target state stands higher than human rights in the scale of values of contemporary international society. The law that prohibits unilateral humanitarian intervention has reflected the judgement of the community that the justification for humanitarian intervention is often ambiguous and accompanied by other motivations. In other words, the law against unilateral intervention

191 See Kahn, "From the Nuremberg to The Hague: The United States' position in Nicaragua $v$. United States and the development of international law”, 12 YaleJIL (1987), at 47.

192 See ICJ Rep. 1970, paras. 33-34.

193 See GA Res. 2625. See also Declaration on the Inadmissibility of Intervention, GA. Res.2131 (XX), UN Doc. A 6014 (21 December 1965).

194 See Legality of Use of Force Case (1999), supra n. 5. See also ICJ website at www.u-paris2.fr/cij/ icjwww/ipres...ss1999/ipresscom9923_iyall_19990602.htm. 
established in the UN Charter emphasises that no individual state can be entrusted with the authority to judge and determine wisely. The situation in the world today, particularly since the two catastrophes in Bosnia and Kosovo, and the fact that the international community has moved toward the creation of stronger international human rights law, has led some writers such as Charney ${ }^{195}$ to suggest that the development of a new rule of law that permits intervention by regional organizations to stop such crimes without the Security Council's authorization would be appropriate. In my view there is a need neither to change the current rule nor to create allowing humanitarian intervention a new rule that could provide a pretext for abusive intervention under international law. The present ambiguous situation or acquiescence in a violation considered necessary and desirable in the particular circumstances are preferable to the adoption of a new rule which, by allowing unilateral intervention without Security Council authorization, would be wide open to abuse.

195 See J.I. Charney, “Anticipatory humanitarian intervention in Kosovo”, 93 AJIL (1999), at 834845 . 